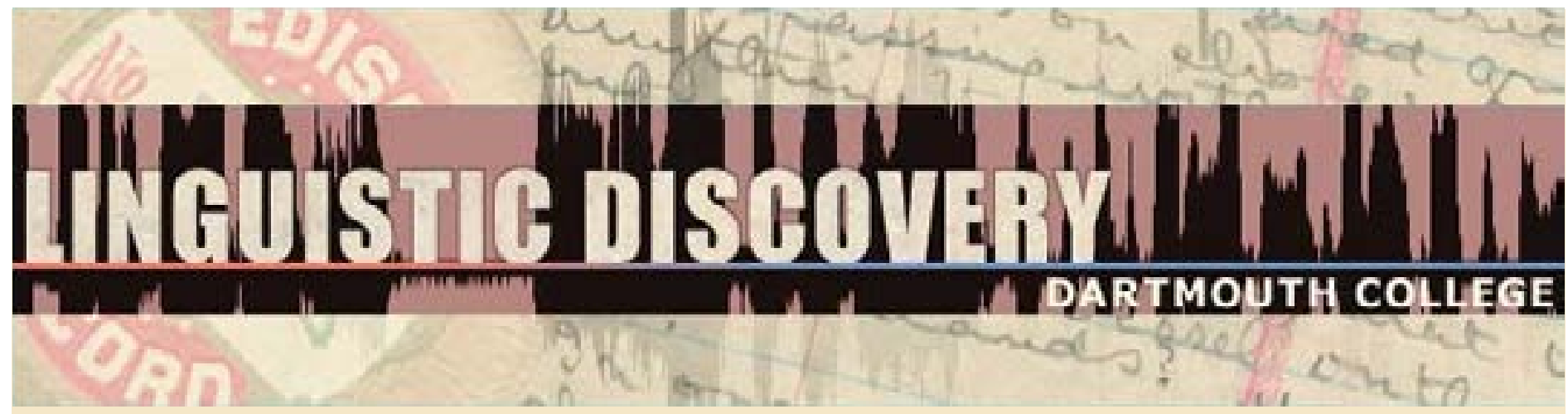

Volume 4 Issue 1 2006
$\mathrm{Na}(\mathrm{t})$ ive Orthographies and Language Endangerment: Two Case Studies from Siberia

K. David Harrison ${ }^{*+} \&$ Gregory Anderson ${ }^{\dagger}$

*Swarthmore College \& ${ }^{\dagger}$ MPI Leipzig

doi: 10.1349/PS1.1537-0852.A.304

url: http://journals.dartmouth.edu/cgi-bin/WebObjects/ Journals.woa/1/xmlpage/1/article/304 


\section{Na(t)ive Orthographies and language endangerment \\ Two case studies from Siberia}

(from the poster presented at LSA 2005)

K. David Harrison ${ }^{\dagger}$ \& Gregory Anderson ${ }^{\dagger}$

*Swarthmore College $\&{ }^{\dagger}$ MPI Leipzig

\section{Introduction}

In this poster, we present findings on the invention and use of naïve (native) orthographies among two vanishing minority groups of central Siberia, the Ös (also called Middle Chulym) and the Tofa. Despite small numbers of speakers, both of these moribund languages have recently acquired native literary and orthographic traditions: one introduced from above, by linguists, and another invented by a member of the speech community. We documented patterns of use and adaptation of these two systems, as well as attitudes expressed by towards them by individuals.

Specific developments in the conventional use of graphemes shed light on the psychological reality of phonemes and phonological and prosodic processes. Attitudes towards new writing systems as well as their uses help to elucidate the politics of literacy.

\subsection{History and demography}

Unlike the vast majority of indigenous minority languages of the former Soviet Union, neither Tofa [kim] nor Ös [clw] were ever officially committed to writing in a state-sanctioned bilingual program. Instead they suffered, to varying degrees, the consequences of open hostility from the state. Despite adverse conditions, both communities have shown a nascent indigenous literary 
tradition and native attempts to codify the once active oral literary tradition before it is lost altogether.

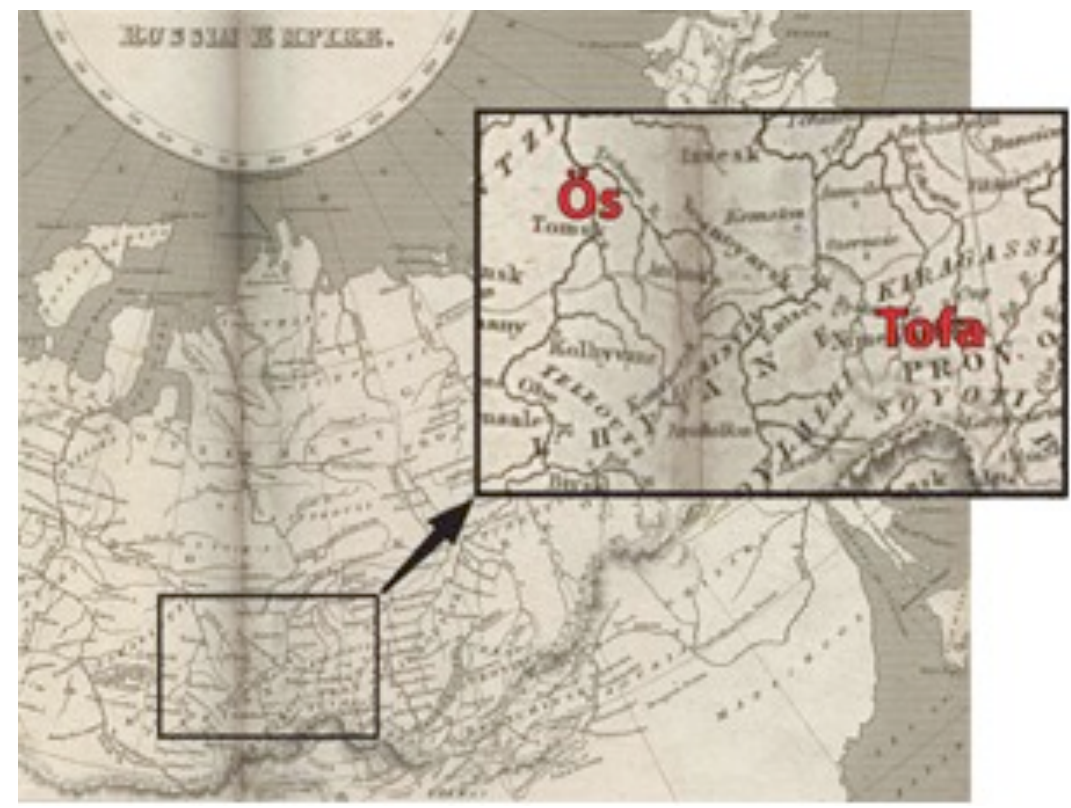

Figure 1a: Historical map with locations of Ös and Tofa indicated. Map from The Cyclopaedia or, Universal Dictionary of Arts, Sciences, and Literature by Abraham Rees, 1820, Courtesy of the University of Texas Libraries, University of Texas at Austin

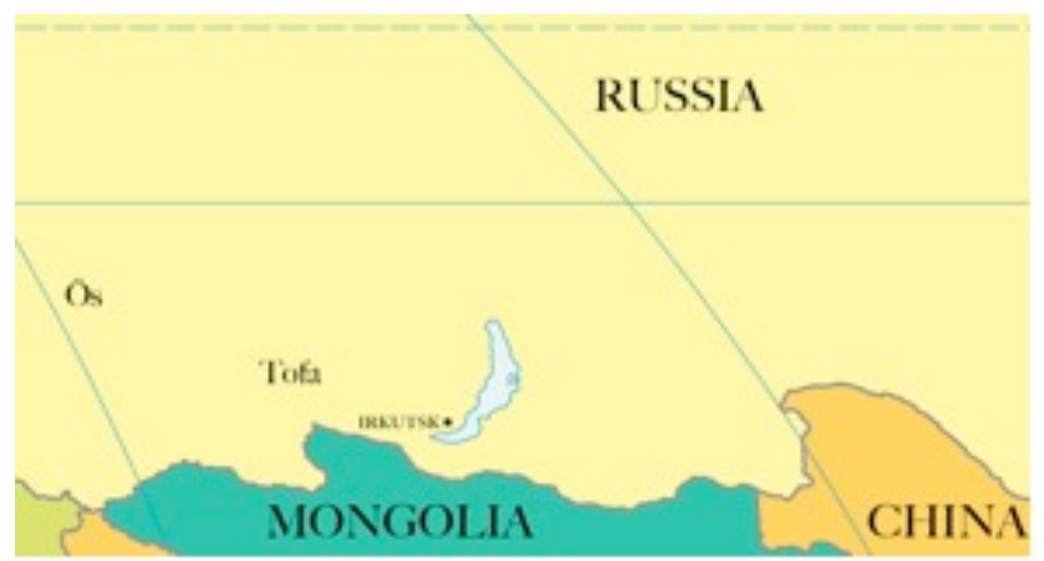

Figure 1b: Modern schematic map for comparison. 


\section{Tofa}

The Tofa live in three remote villages in east-central Siberia, Irkutsk region. They are subsistence hunter-gatherers and reindeer herders in the eastern Sayan mountains of Siberia. Although the Tofa number around 600 persons, only 35 still speak the Tofa language.

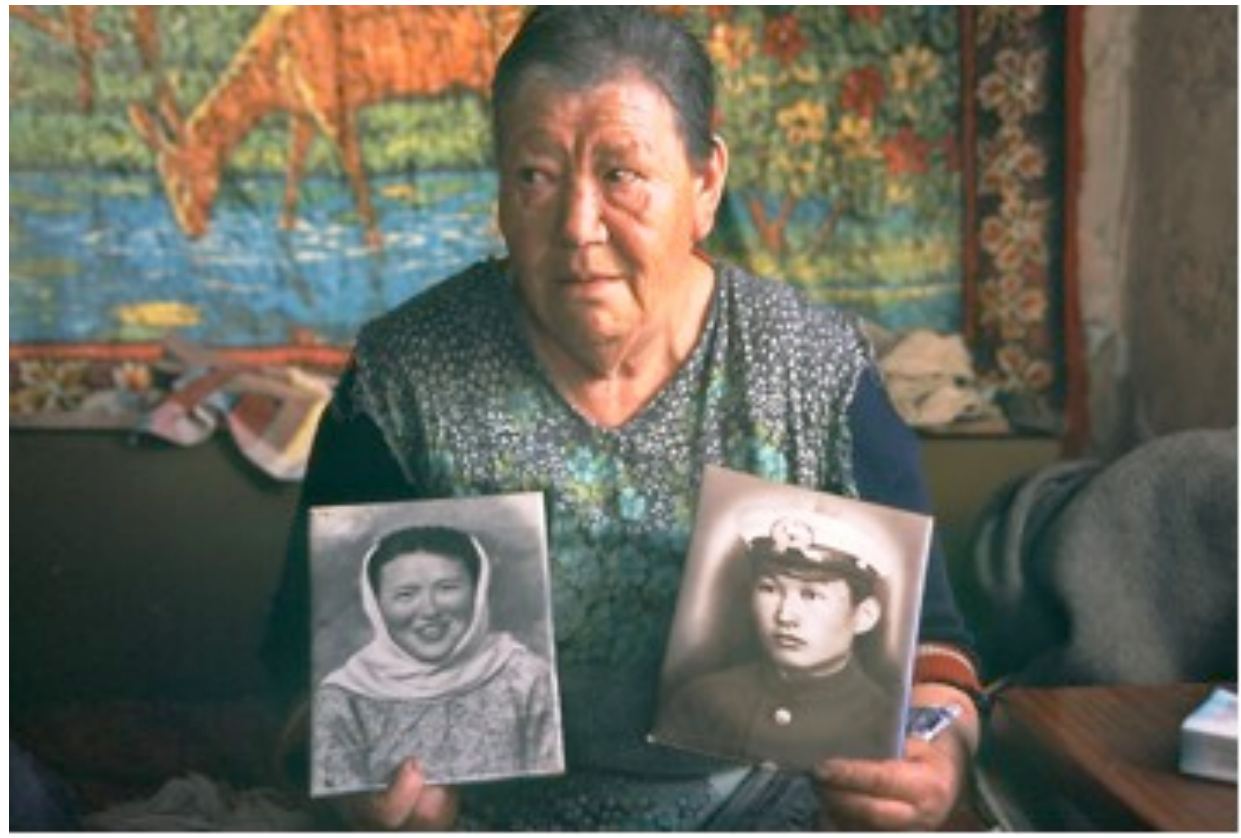

Figures 2 and 3: Tofa consultants Marta Kongaraeva (above) and her son (below) Sergei Kangaraev.

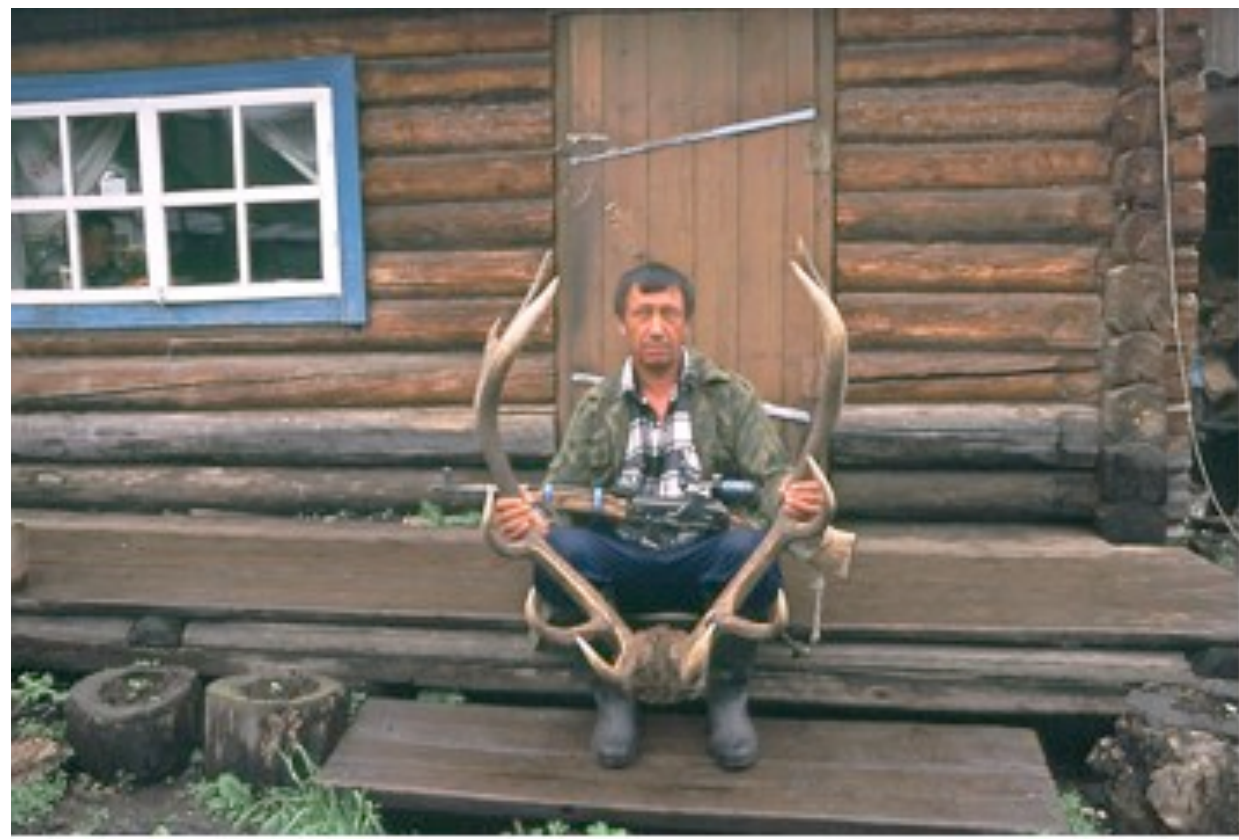




\subsection{Official orthography}

While the Tofa never received an orthography from the Soviet state, they were presented one in 1989 from a linguist, V. I. Rassadin, who married a member of the community but lived permanently outside it. It was based on Cyrillic and included a total of nine new letters lacking in the Russian form of the script.

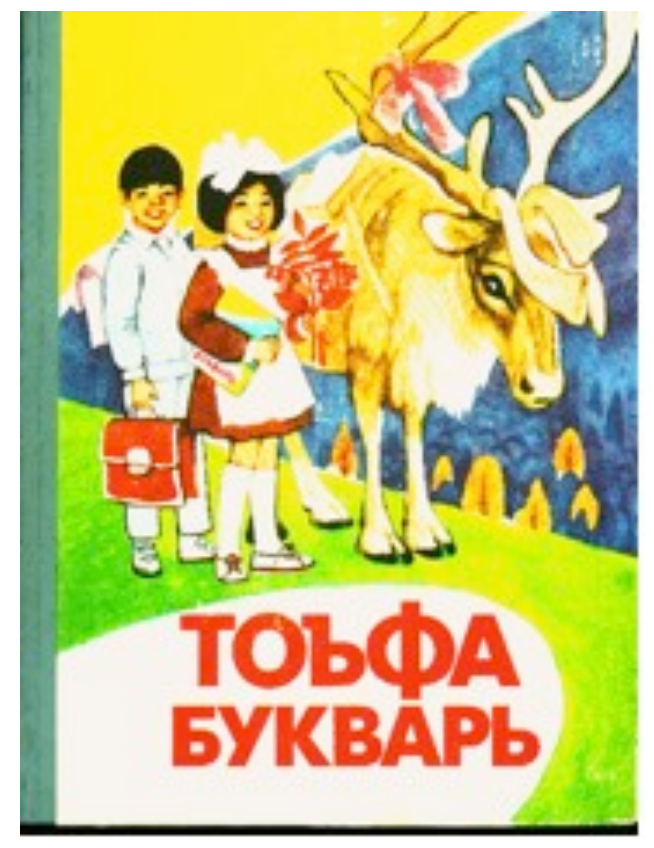

Figure 4: ABC book with 'official' Tofa orthography

Created with virtually no native input, the script was also linguistically unsound, encoding many sub-phonemic distinctions.

\section{2 "Too many letters"}

Although there were 3 storybooks (e.g., Rassadin and Shibkeev 1989) and a Russian-Tofa dictionary (Rassadin 1995) published with the script, it never gained many users; the community rejected it as too complex and cumbersome. Speakers complained that it had "too many letters." In our 2001 survey of the Tofa-speaking community, we found this orthography actively used by 
only a single person, a semi-speaker who was charged with conducting basic vocabulary lessons for local schoolchildren.

\subsection{Native modified writing}

However, for the last decade or so, accomplished Tofa storytellers and others literate in Russian have attempted a variety of independent, though not necessarily systematic, 'naïve' orthographic to simplify and rationalize Tofa letters, adopting new conventions that make sense for Tofa.

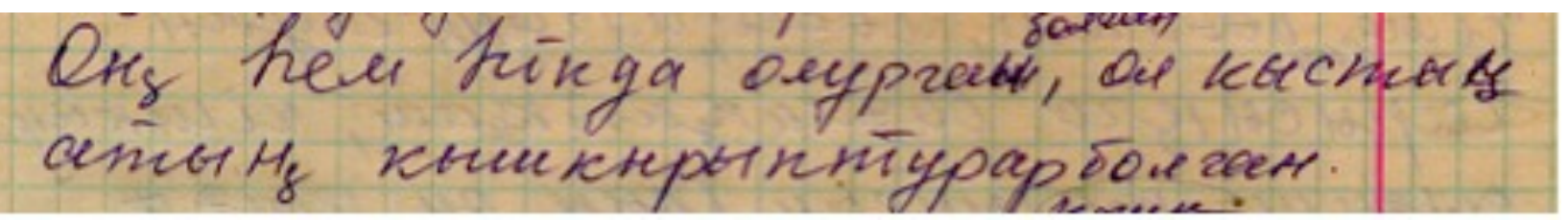

Figure 5: "He sat down by the riverbank and began calling out that girl's name." (Svetlana Araktaeva, 2002)

\subsection{Phonological decisions}

One such system, that of Svetlana Araktaeva, is shown in figure 5. In this sample, contrastive vowel length is ignored, front vowels are rendered as palatal consonant + vowel, and the Russian 'hard' sign $<\mathrm{b}>$, which has no meaning for Tofa, is re-utilized to indicate low pitch on a preceding vowel. Vowel harmony, though highly variable, is shown in writing.

\subsection{Morphosyntax}

Araktaeva's writing also sheds light on perception of word boundaries and the structure of serial verbs. In the writing sample shown here, she conflates three serial verbs into a single written word, indicating perhaps an ongoing process of univerbation. 
(3) kifkırıpturarbolgan

kifkir-ip tur-ar bol-gan

call.out-CV AUX-PF COP-PAST

(he) kept standing and calling out

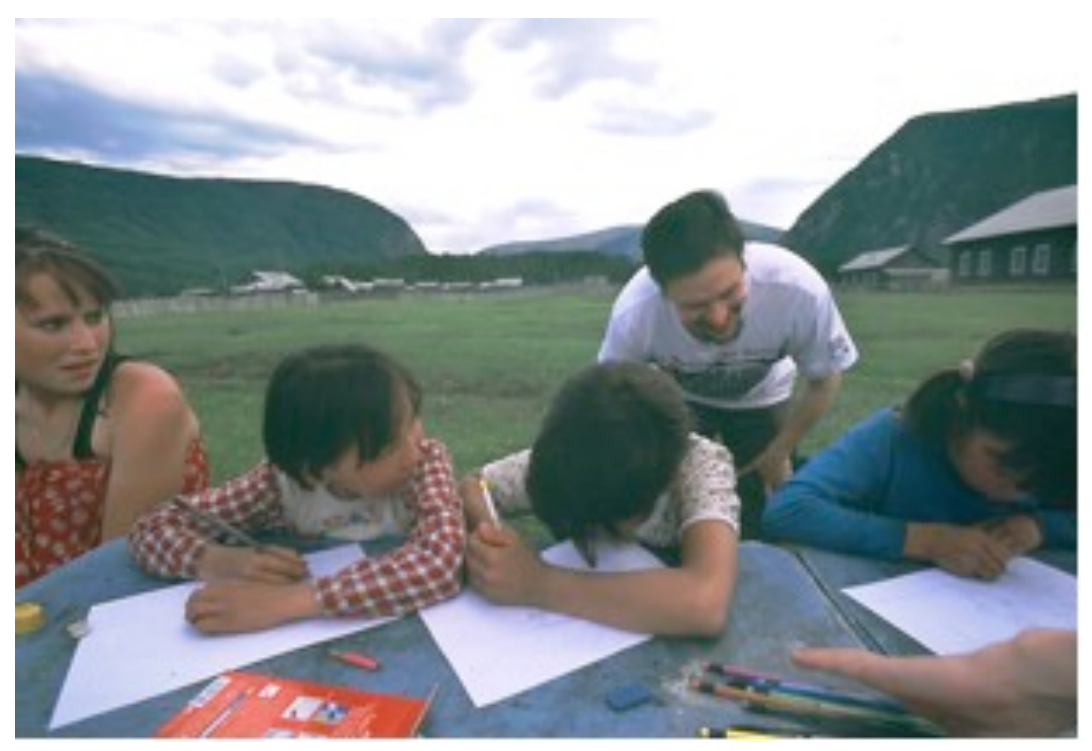

Figure 6: Photograph of Tofa children illustrating "Tofa Tales." 


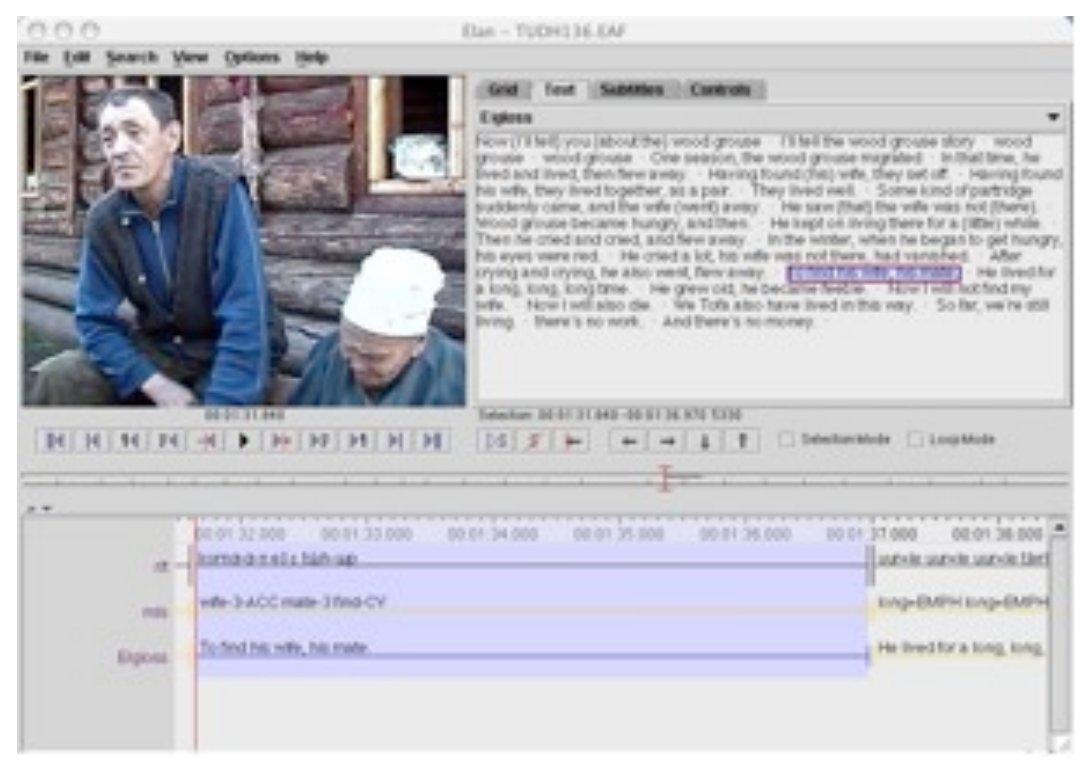

Figure 7: An annotated screen shot of Konstantin Mukhaev telling a Tofa story.

\section{3. Ös}

The Ös people of Central Siberia, also called 'Middle Chulym', are traditional hunter-gatherers $\&$ fishermen living in the Tomsk region of central Siberia. The Ös tribe has 726 members, but the language is spoken by fewer than 40 people scattered across seven villages.

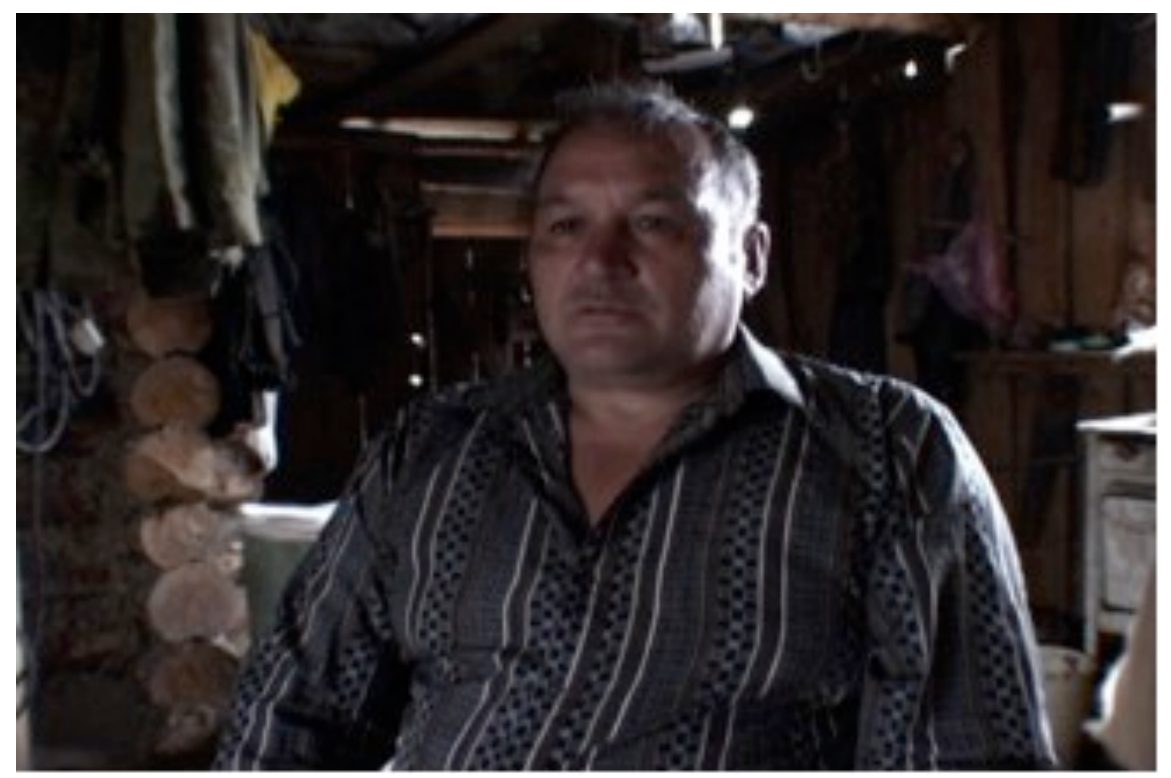

Figure 8: Ös consultant Vasillij Gabov describes how he invented his own writing system. 
There has never been an attempt to devise an orthography for Ös, in part due to the open hostility directed toward the people from the Russian state: writing is Ös was forbidden and the language repressed. For a variety of socio-political reasons, the Ös were dropped from the census as a separate ethnic group in 1959, and incorrectly lumped together with other ethnic groups. Official re-recognition happened only in 1998, and the Ös have seen few tangible results. 


\section{1 Ös writing invented, then abandoned.}

Despite the lack of an official orthography for Ös, one member of the community, Vasillij

Gabov, devised a remarkably ingenious Russian-based orthography to render this phonetically quite different language. In 2003, Gabov told us how he had discarded his book and abandoned writing after being ridiculed by a Russian member of the community (1-26).

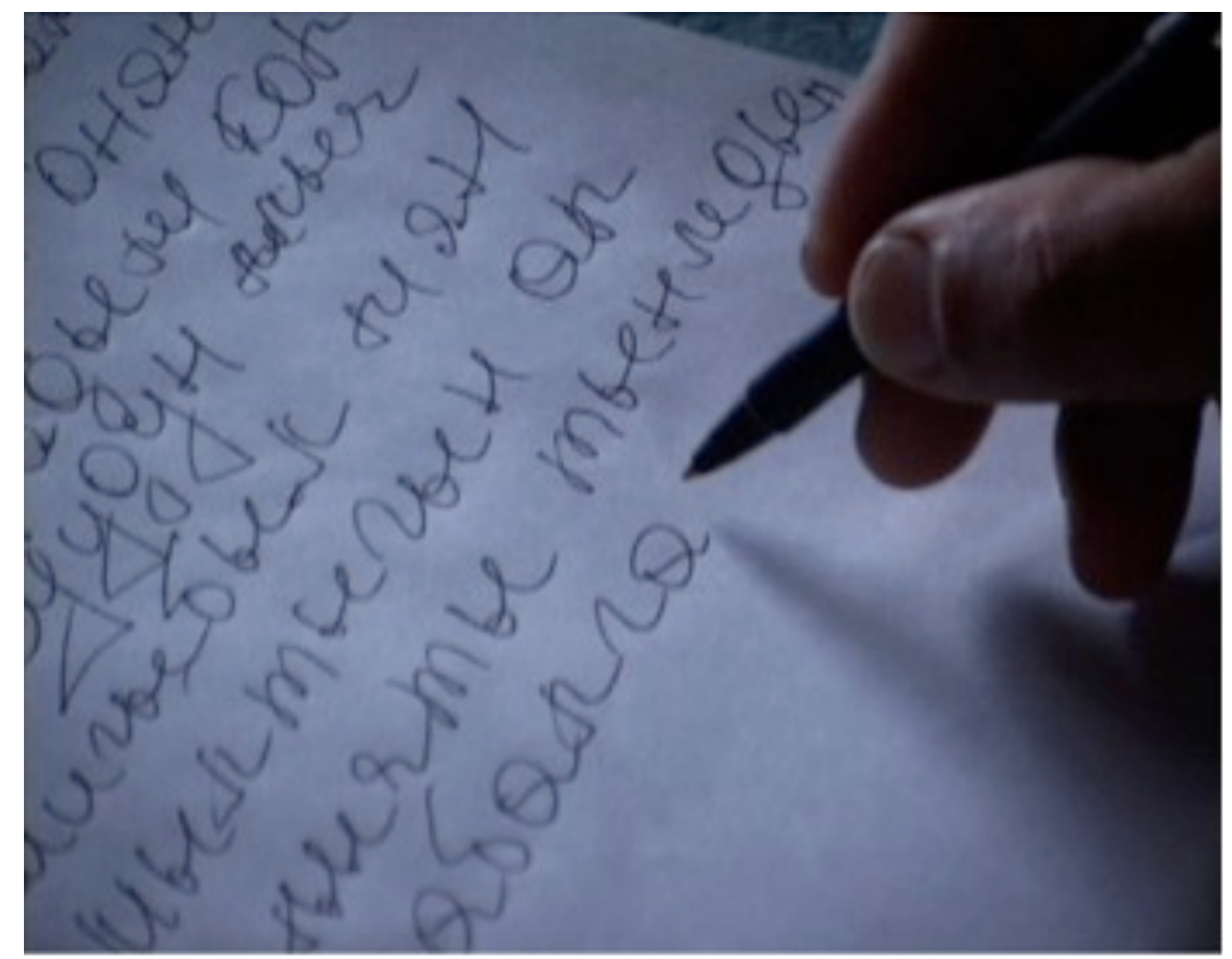

Figure 9: Screenshot of Gabov's hand writing Ös

(1) men tayya-da tfejit bol-ya-m

I taiga-LoC young be-PST-1

'When I was young out in the taiga' 
(2) tajya-da siree t tør-ej-m

taiga-LOC always go-ASP-1

'I always used to go about in the taiga'

(3) no anda meey qayas bol-yan

(R)and there 1:GEN paper be-PST

'And there I had some paper'

(4) men ærtæn jesli bar-za-m aalif-ti-ige

I morning (R)if go-COND-1 moose-VSF-INF

'In the morning if I would go moose hunting,'

(5) no nøøn[e] bol-za tav-arya iir-ge kæl-ze-m

(R)and thing be-COND find-INF evening-DAT come-COND-1

'And if anything happened, when I returned in the evening'

(6) tygæde fija-a-m po qayas-qa jija-t-um nø-ny æt-ke-m always write-PST-1 that paper-DAT write-HAB-1 thing-ACC do-PST-1 I would always write, I would write what I did on that paper 
(7) ærtæn øS saam andun men pajdaq anda ji-j bol-ya-m morning self (R)self from.there I much there write-CV AUX-PsT-1 'in the morning I myself had written a lot there'

(8) a po kyd-ys-ke-m qayeez-in qazaq kiz-ee and that show-PRF-PST-1 paper-3:ACC Russian person-DAT 'and I showed it, the paper, to a Russian person'

(9) a ol ajd-ubul nø-ny munaar Jij-ip sal-ya- $\eta$ and $\mathrm{s}$ /he say-PRES thing-ACC to.here write-CV AuX-Pst-2 'and he said, what's that thing you have written here?

(10) a men anu no aydun køre-p sal-ya-m and I it-ACC (R)DISC 3:ABL throw-CV AUX-PST-1 'So I threw it away'

(11) a jij-ba-a-m anzon-da (R)and write-NEG-PST-1 afterwards-EMPH 'And since then I haven't written (anything).' 
(12) men sybyr no tunna-p pa-ya-m

I bad (R)DISC hear-CV AUX-PST-1

'After I heard that bad thing:'

(13) andun sen Jij-ip-tur-zum sen

from.there you write-CV-EVID-2 you

"What have you written there"

(14) tadar til-le qaja Sij-ik-tur

Chulym language-INS why write-FUT-ASSRTV

Why would (you) write in Chulym?

(15) men andun Jij-ba-a-m

I $\quad 3: \mathrm{ABL} \quad$ write-NEG-PST-1

'After that I didn't write (any more)'

(16) anzon køre-p sal-ga-m po qayas-tu

afterwards throw-CV AUX-PST-1 that paper-ACC and threw away that paper.' 
(17)

men kyt-ys-ke mozet siler-ge pol-ya-m

I show-PRF-INF (R)maybe you.PL-DAT AUX-PST-1

'Maybe I would have shown it to you,'

(18) azu tfoyul qajda tfat quil-yan anda køre-p sal-ya-m

or NEG:COP where lie AUX-PST there throw-CV AUX-Pst-1

'But it doesn't exist anymore; it's still there where I threw it away.'

(19) æmde Jij-ar tfoy-um

now write-P/F NEG-1

'Now I don't write'

(20) men siler-ga ajd-urga pol-ga-m anu

I you-DAT tell-INF AUX-PST-1 it:ACC

'I wanted to tell you this.'

(21) men tygeedi øs til-ni qunaa-dus-m

I always Ös language-ACC love-HAB-1

'I have always loved the Ös language' 
(22)

tfurtta-bul-mun os til-ni saad-urbul-mun

live-PRES-1 Ös language-ACC speak-PRES-1

'I live, and speak the Ös language'

(23) øs til-ni t tjaqfu saad-ubbul-mun

Ös language-ACC beautiful speak-PRES-1

'I speak the Ös language very well'

(24) ii idzaa-m bol-gan toze ajt-qan-nar

(R)and mother-1 be-PST (R)also say-PST-PL

'And my mother also used to say'

(25) Sto øs-tun til-ni tadar til-ni saat-arga $\quad$ kerek

(R)that Ös-GeN language-ACC Ös language-ACC speak-INF NEC

'That it's necessary to speak the language of the Ös, the Tatar (Ös) language'

(26) qazaq qazaq-tar-ga tadar tadar-lar-ga

Russian Russian-PL-DAT Ös Ös-PL-DAT

'Russian is for the Russians and Ös is for the Ös' 


\subsection{Phonological decisions}

Figure 10 shows an example of Gabov's orthography. No new symbols were introduced to the Russian Cyrillic, but script was made to fit Ös. Gabov modified the orthography using novel combinations. For instance, the Russian 'soft sign' $<\mathrm{b}>$ can be used after the first non-initial consonant to indicate that all vowels in the word are front. This solution implicitly recognizes vowel harmony operating across entire word-domains.

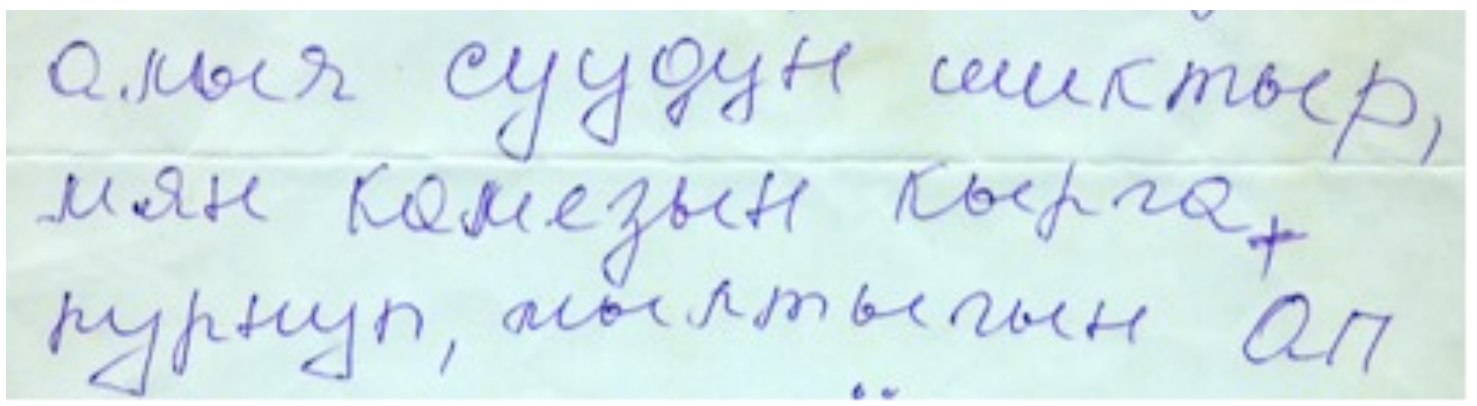

Figure 10: "The moose emerged from the water, I brought my boat to shore, grabbed my gun, and..." (Gabov, 2003)

\subsection{Linguists' Contributions}

The authors worked with this speaker to revive his orthography and produce a Middle Chulym storybook. Preliminary studies show this orthography to be easily accessible to other members of the community. The first Ös book ever published to appear in 2005. It uses Gabov's orthography and features stories and illustrations by community members. We field tested it in 2005 and it got positive reactions from community members, several of whom were able to read it aloud. We estimate the potential readership is $20-25$ persons, but as an item of linguistic prestige, we expect it will have wider impact. 


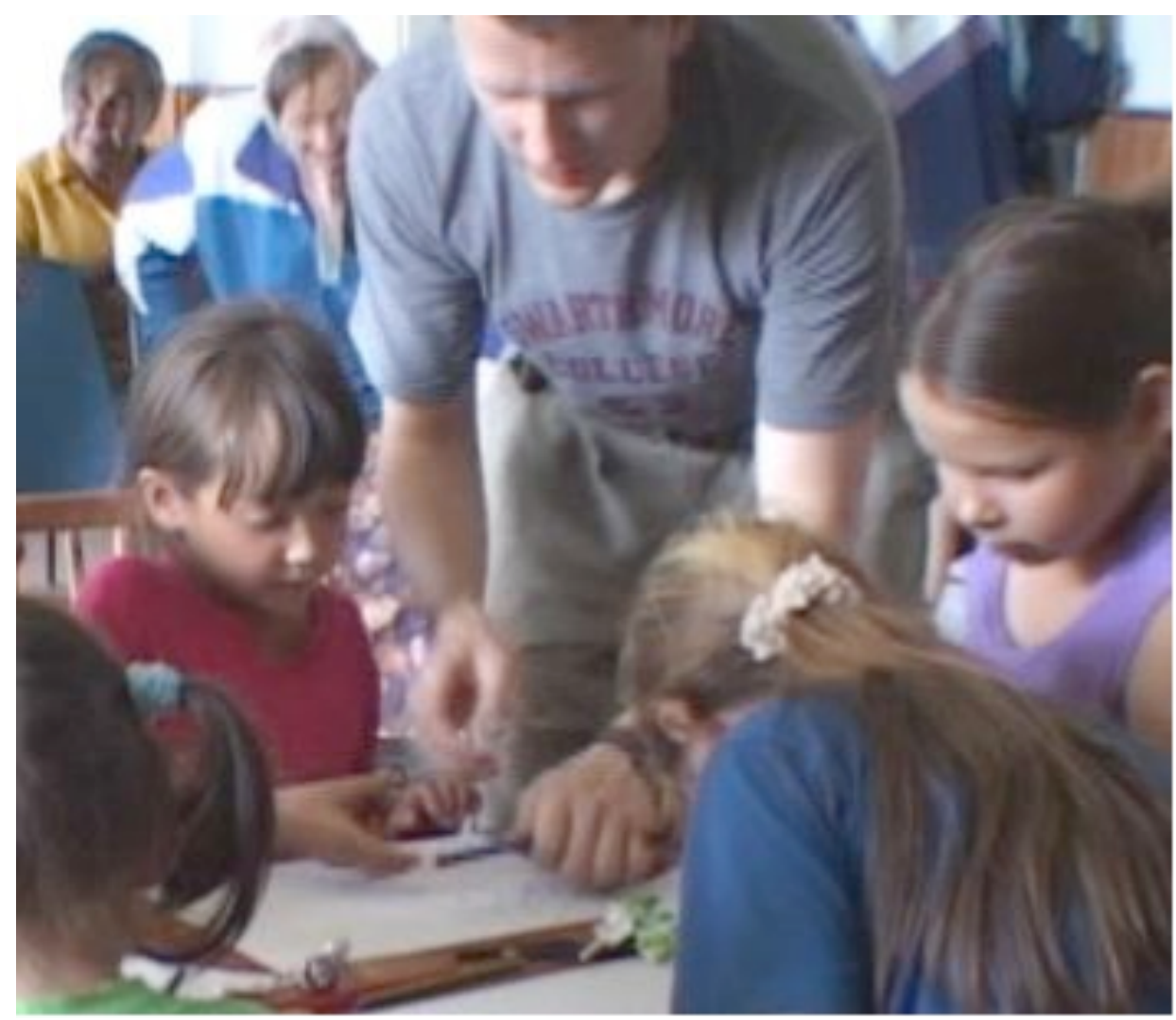

Figure 11: Ös children illustrate the storybook: frame from forthcoming film The Last Speakers 


\begin{abstract}
Алыч
Артян туруп, кун гарагы шикпанча, мян мылтыгын ап чердюпскем кольге. Кольдя мен камям полган. Камя олуруп амьда парыдым.

Дось - Я утром стал, до восхода солвца, взял своё ружьё и отправился $\mathrm{K}$ оэеру. у озера был обаасок моя. Я сел в обласок и отппавиася.

Moose - 'I got up in the morning before the sun mose, took my gun and set off to the lake.' 'My boat was at the lake. I sat in my boat and set off.'
\end{abstract}

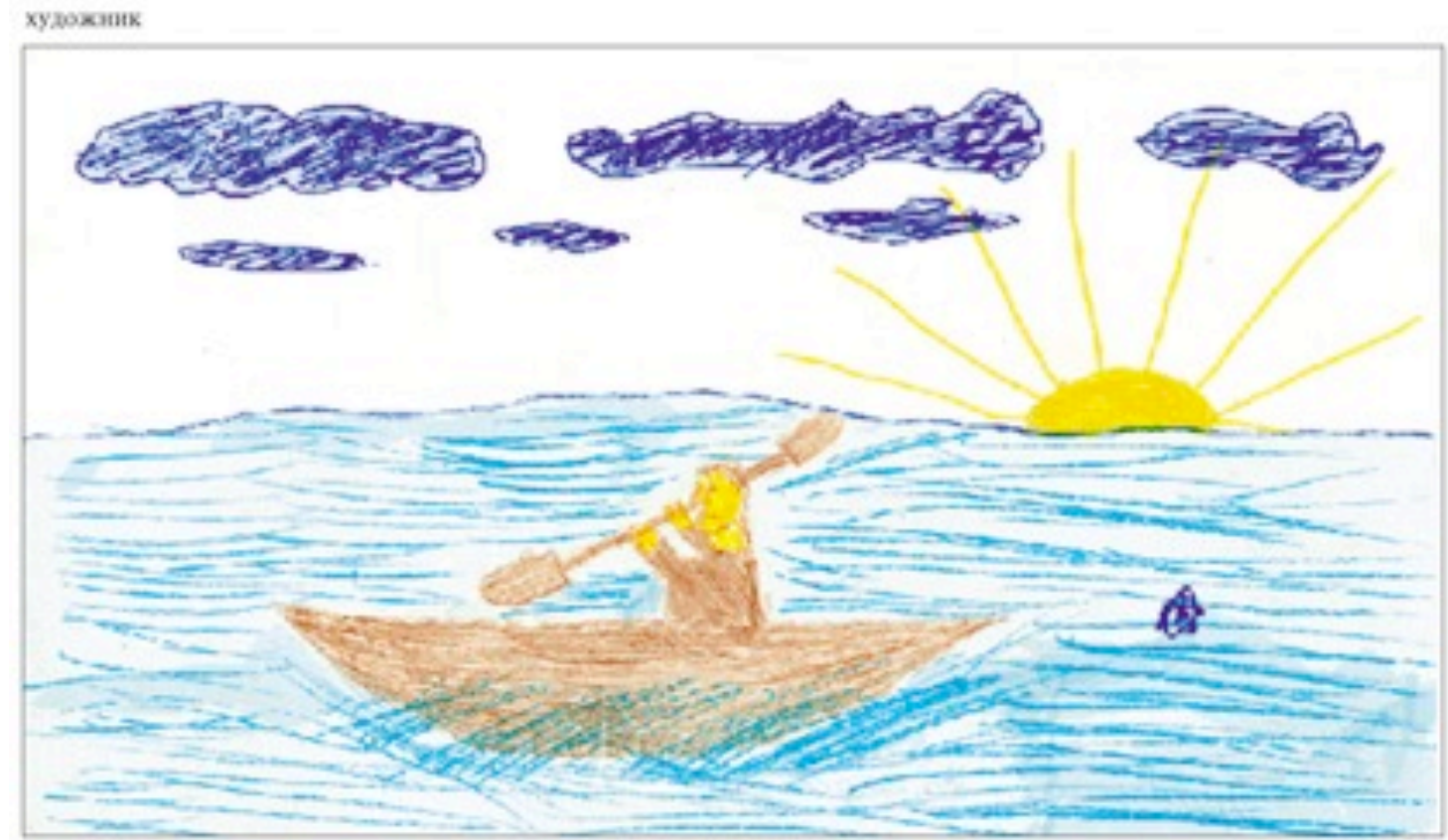

Figure 12: Page of Ös children's book 


\section{References}

various (2006 forthcoming) Ös chomaktary: Middle Chulym Tales. Prepared and translated by

Gregory D. S. Anderson and K. David Harrison, with stories by V. Gabov and I. Skoblin.

Eugene, OR: Living Tongues Institute for Endangered Languages.

Kramer, Seth and Daniel Miller, producers (2006). The Last Speakers. New York, NY:

Ironbound Films.

Rassadin, V. I. and V. N. Shibkeev. 1989. Tofa bukvar. Irkutsk: VSKO.

Rassadin, V. I. 1995. Tofalarsko-russkij russko-tofalarskij slovar’. Irkutsk: VSKO. 